\title{
Cognitive impairments in survivors of out-of-hospital cardiac arrest: a systematic review
}

Citation for published version (APA):

Moulaert, V. R. M. P., Verbunt, J. A., van Heugten, C. M., \& Wade, D. T. (2009). Cognitive impairments in survivors of out-of-hospital cardiac arrest: a systematic review. Resuscitation, 80(3), 297-305. https://doi.org/10.1016/j.resuscitation.2008.10.034

Document status and date:

Published: 01/01/2009

DOI:

10.1016/j.resuscitation.2008.10.034

Document Version:

Publisher's PDF, also known as Version of record

Document license:

Taverne

Please check the document version of this publication:

- A submitted manuscript is the version of the article upon submission and before peer-review. There can be important differences between the submitted version and the official published version of record.

People interested in the research are advised to contact the author for the final version of the publication, or visit the DOI to the publisher's website.

- The final author version and the galley proof are versions of the publication after peer review.

- The final published version features the final layout of the paper including the volume, issue and page numbers.

Link to publication

\footnotetext{
General rights rights.

- You may freely distribute the URL identifying the publication in the public portal. please follow below link for the End User Agreement:

www.umlib.nl/taverne-license

Take down policy

If you believe that this document breaches copyright please contact us at:

repository@maastrichtuniversity.nl

providing details and we will investigate your claim.
}

Copyright and moral rights for the publications made accessible in the public portal are retained by the authors and/or other copyright owners and it is a condition of accessing publications that users recognise and abide by the legal requirements associated with these

- Users may download and print one copy of any publication from the public portal for the purpose of private study or research.

- You may not further distribute the material or use it for any profit-making activity or commercial gain

If the publication is distributed under the terms of Article $25 \mathrm{fa}$ of the Dutch Copyright Act, indicated by the "Taverne" license above, 
Review article

\title{
Cognitive impairments in survivors of out-of-hospital cardiac arrest: A systematic review ${ }^{\text {t3 }}$
}

\author{
Véronique R.M.P. Moulaert ${ }^{\mathrm{a}, *}$, Jeanine A. Verbunt ${ }^{\mathrm{a}, \mathrm{b}}$, Caroline M. van Heugten ${ }^{\mathrm{c}, \mathrm{d}}$, Derick T. Wade ${ }^{\mathrm{a}, \mathrm{e}}$ \\ ${ }^{a}$ Rehabilitation Foundation Limburg, Hoensbroek, The Netherlands \\ b Department of General Practice, Maastricht University, Maastricht, The Netherlands \\ ${ }^{\mathrm{c}}$ Department of Psychiatry and Neuropsychology, School for Mental Health and Neuroscience, Maastricht University, The Netherlands \\ d Utrecht Centre of Excellence for Rehabilitation Medicine de Hoogstraat, Utrecht, The Netherlands \\ e Oxford Centre of Enablement, Oxford, United Kingdom
}

\section{A R T I C L E I N F O}

\section{Article history:}

Received 24 April 2008

Received in revised form 10 October 2008

Accepted 14 October 2008

\section{Keywords:}

Cardiac arrest

Resuscitation

Cognitive impairments

Cognition disorders

Neuropsychological tests

\begin{abstract}
A B S T R A C T
Objective: To describe the current evidence on the frequency and nature of cognitive impairments in survivors of out-of-hospital cardiac arrest.

Design: Systematic review.

Data sources: Pubmed, Embase, PsychInfo and Cinahl (1980-2006). No language restriction was imposed. Review methods: The following inclusion criteria were used: participants had to be survivors of out-ofhospital cardiac arrest, 18 years or older, and there had to be least one cognitive outcome measure with a follow-up of 3 months or more. Case reports and qualitative studies were excluded. The articles were screened on title, abstract and full text by two reviewers. All selected articles were reviewed and assessed by two reviewers independently using a quality criteria list.

Results: Out of the 286 articles initially identified, 28 were selected for final evaluation. There was a high heterogeneity between the studies with regard to study design, number of participants, outcome measures and duration of follow-up. In general, the quality of the articles appeared low, with a few positive exceptions.

The reported frequency of cognitive impairments in survivors of out-of-hospital cardiac arrest ranged from $6 \%$ to $100 \%$. Memory problems were the most common cognitive impairment, followed by impairments in attention and executive functioning. Three high-quality prospective studies found that cognitive problems occurred in about half of the survivors of out-of-hospital cardiac arrest.

Conclusion: There are few good studies on the frequency of cognitive impairments after out-of-hospital cardiac arrest. However, cognitive problems, in particular memory problems, seem common in survivors of out-of-hospital cardiac arrest.
\end{abstract}

(C) 2008 Elsevier Ireland Ltd. All rights reserved.

\section{Contents}

1. Introduction

2. Methods ...

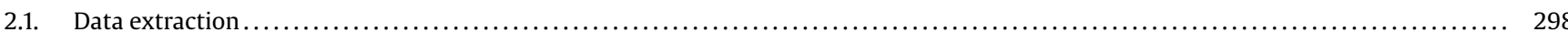

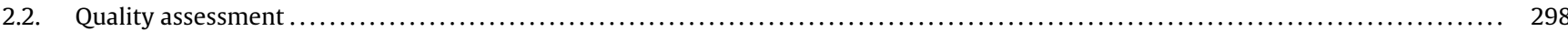

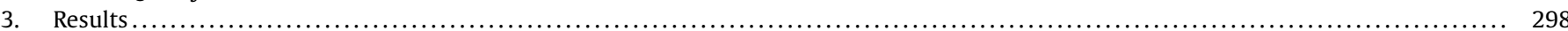

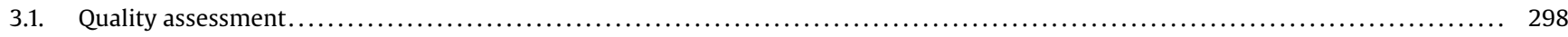

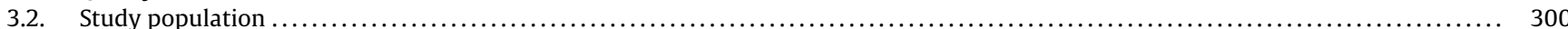

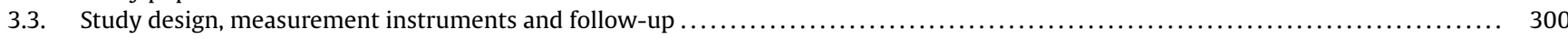

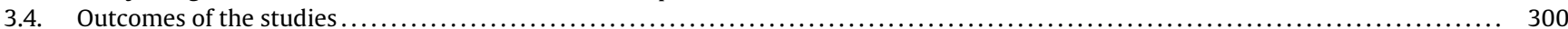

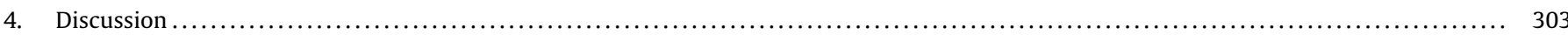

\footnotetext{
is A Spanish translated version of the summary of this article appears as Appendix in the final online version at doi:10.1016/j.resuscitation.2008.10.034.

* Corresponding author at: Véronique RMP Moulaert, Rehabilitation Foundation Limburg, Zandbergsweg 111, 6432 CC Hoensbroek, The Netherlands Tel.: +31 455282358; fax: +31455382000 .

E-mail address: v.moulaert@srl.nl (V.R.M.P. Moulaert).
} 


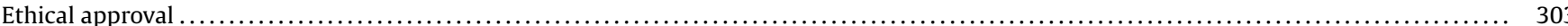

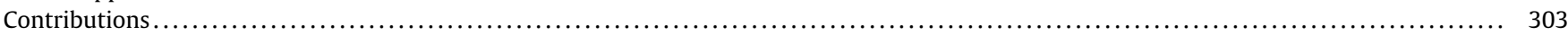

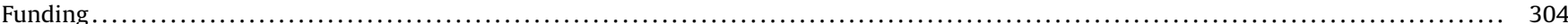

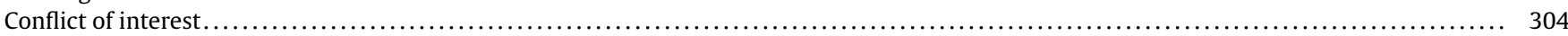

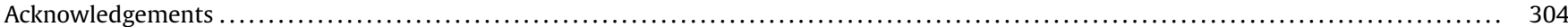

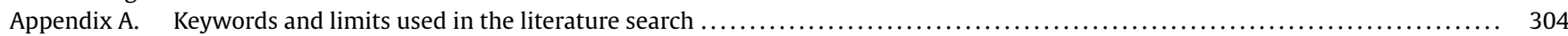

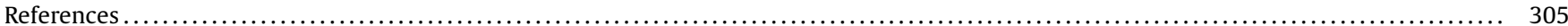

\section{Introduction}

During a cardiac arrest the brain can suffer from a temporary limitation in blood supply, which can lead to hypoxic brain injury. One of the main clinical consequences of hypoxic brain injury is cognitive impairment. Although cognitive impairments may not be directly visible, they can affect a person's life greatly in daily activities, in participation in society and in quality of life. ${ }^{1-3}$ It is currently unclear how often cognitive impairments occur after a cardiac arrest, and what kind of cognitive problems occur most frequently. Existing publications, dedicated to cognitive function after cardiac arrest, vary in study design, research population and outcome measures used. Some studies report that the incidence of neurological sequelae is remarkably low, ${ }^{4,5}$ while others state that survivors of out-of-hospital cardiac arrest are seriously disabled because of their neuropsychological deficits. ${ }^{6,7}$ To our knowledge, evidence on this topic has not yet been reviewed systematically. The aim of this study is to review systematically current evidence on the frequency and nature of cognitive impairments in survivors of out-of-hospital cardiac arrest.

\section{Methods}

A systematic literature search was performed using the databases Pubmed, Embase, PsychInfo and Cinahl. Details on the search strategies are presented in Appendix 1. The literature search was performed by the first reviewer (VM) in March 2007. The publications for this review were selected based on the inclusion criteria as described in Table 1.

Two independent reviewers (VM+JV) selected eligible articles (see Fig. 1 for flowchart of the selection process). If the two reviewers disagreed and consensus could not be reached, the third reviewer $(\mathrm{CvH})$ made the final decision. An additional hand search was performed in which the references of the articles selected $(n=36)$ were tracked and personal files of the first reviewer were searched.

Of the 43 articles that were read in full text, all except four were written in English. There were two articles written in German, one in French and one in Hungarian. The Hungarian and French articles were reviewed after translation by native speakers with medical backgrounds.

\subsection{Data extraction}

The first reviewer (VM) extracted the following data from the articles on a structured form: author, year of publication, study

Table 1

Inclusion criteria for the selection of publications.

\begin{tabular}{ll}
\hline Participants & Survivors of out-of-hospital cardiac arrest and $>18$ years old \\
Type of study & No case-reports or qualitative studies \\
Outcome measure & Cognitive functioning \\
Follow-up & $>3$ months after the cardiac arrest \\
Year of publication & $1-1-1980-31-12-2006$ \\
Language & No restriction \\
\hline
\end{tabular}

design, in/exclusion criteria, years of data collection, number of participants, age distribution, characteristics of the control group (if present), outcome measures used, duration of follow-up and the frequency and kind of cognitive impairments. The second reviewer checked the extracted data.

\subsection{Quality assessment}

The methodological quality of the selected studies was assessed by the two reviewers independently using an adapted version of the quality criteria scoring list of Hayden. ${ }^{8}$ The original criteria scoring list was adapted for our research: one of the six original domains, 'measurement of prognostic factors', was removed because this was beyond the scope of our review. The final quality criteria scoring list intends to measure the risk of bias on five important methodological domains in prognostic cohort studies, namely study participation, study attrition, outcome measurement, study confounding and statistical analysis/presentation. The risk of bias per domain was summarised as low, moderate, or high. To compare the quality of the various studies, we combined the scores on the five domains into one overall quality score. Domains with a low risk of bias received two points, domains with moderate risk of bias one point, and in case of high risk of bias no points were given. This resulted in a total score ranging from 0 (indicating very poor quality) to 10 (indicating excellent quality). A copy of the quality criteria list used can be provided on request to the first author.

\section{Results}

The initial literature search resulted in 286 titles, extracted from the four databases. Further selection based on title, abstract and full text, resulted in a final selection of 28 articles (see Fig. 1). In Table 2 , the inter-observer agreement in the different stages of the selection process can be found.

\subsection{Quality assessment}

Consensus on quality was reached in all except three articles, for which the third reviewer was consulted. The total quality scores ranged between 0 (very poor) and 10 (excellent). The majority of the articles, 22 (79\%), received a score of 6 or below. Only six studies had a total score higher than $6 .^{9-14}$ The study of van Alem was the only study that received the maximum score of $10{ }^{12}$

Table 2

Agreement between the reviewers during selection process of the articles.

\begin{tabular}{lccc}
\hline $\begin{array}{l}\text { Selection of articles } \\
\text { based on }\end{array}$ & $\begin{array}{l}\text { Direct agreement } \\
\text { between first and } \\
\text { second reviewer }\end{array}$ & $\begin{array}{l}\text { Agreement based } \\
\text { on consent }\end{array}$ & $\begin{array}{l}\text { Decision by third } \\
\text { reviewer }\end{array}$ \\
\hline Title & $243(85 \%)$ & $34(12 \%)$ & $9(3 \%)$ \\
Abstract & $47(68 \%)$ & $14(20 \%)$ & $8(12 \%)$ \\
Hand search & $9(56 \%)$ & $7(44 \%)$ & - \\
Full text & $43(100 \%)$ & - & - \\
\hline
\end{tabular}


Table 3

Evidence table of the selected studies with a case-control, cross-sectional or retrospective cohort design.

\begin{tabular}{|c|c|c|c|c|c|c|c|}
\hline $\begin{array}{l}\text { Author, year of } \\
\text { publication }\end{array}$ & $\begin{array}{l}\text { Quality } \\
\text { score }\end{array}$ & $\begin{array}{l}\text { Study } \\
\text { design }\end{array}$ & N & $\begin{array}{l}\text { Measurement } \\
\text { instrument(s) }\end{array}$ & $\begin{array}{l}\text { Follow-up in months, } \\
\text { mean/median (S.D./range) }\end{array}$ & $\begin{array}{l}\text { Frequency of cognitive } \\
\text { impairments }\end{array}$ & $\begin{array}{l}\text { Measured domains that were } \\
\text { affected are shown in bold } \\
\text { Measured domains that were not } \\
\text { affected are shown in italics }\end{array}$ \\
\hline Bergner, $1985^{36}$ & 2 & Case-control & 308 & Interview & 7 & $38 \%$ versus $18 \%$ & Memory \\
\hline Bertini, $1990^{4}$ & 4 & Case-control & 30 & $2 \mathrm{np}$ tests & $30(3-57)$ & 'Remarkably low’ & $\begin{array}{l}\text { Memory } \\
\text { Attention/concentration }\end{array}$ \\
\hline Drysdale, $2000^{22}$ & 4 & Case-control & 10 & $2 \mathrm{np}$ tests & 36 & 'More than controls' & $\begin{array}{l}\text { Memory (recall, recognition and } \\
\text { episodic) }\end{array}$ \\
\hline Hopkins, $1995^{17}$ & 5 & Case-control & 11 & $4 \mathrm{np}$ tests & 12 & 'More than controls' & $\begin{array}{l}\text { Memory (especially for novel } \\
\text { info) } \\
\text { Frontal lobe functioning and visual } \\
\text { memory span }\end{array}$ \\
\hline Nielsen, $1983^{18}$ & 2 & Case-control & 13 & $\begin{array}{l}\text { Interview + } 10 \mathrm{np} \\
\text { tests }\end{array}$ & $12-36$ & $54 \%$ versus $31 \%$ & $\begin{array}{l}\text { Memory, subtraction, language, } \\
\text { abstraction }\end{array}$ \\
\hline Grubb, $1996^{9}$ & 8 & $\begin{array}{l}\text { Cross-sectional+ } \\
\text { Case-control }\end{array}$ & 35 & $3 \mathrm{np}$ tests & $7(4.4)$ & $37 \%$ versus $0 \%$ & $\begin{array}{l}\text { Episodic long-term memory } \\
\text { (especially verbal and spatial) } \\
\text { Short term recall }\end{array}$ \\
\hline Grosswasser, $1989^{16}$ & 1 & Cross-sectional & 31 & Not described & $>36$ & $68 \%$ & Thought processes, memory \\
\hline Sauvé, $1995^{20}$ & 3 & Cross-sectional & 61 & Interview & $21(11)$ & $41 \%$ & $\begin{array}{l}\text { Memory, concentration, } \\
\text { comprehension }\end{array}$ \\
\hline Barat, $1989^{15}$ & 1 & $\begin{array}{l}\text { Retrospective } \\
\text { cohort }\end{array}$ & 11 & $7 \mathrm{np}$ tests & 12 & $91 \%$ & Memory, aphasia, apraxia \\
\hline Bunch, $2004^{25}$ & 6 & $\begin{array}{l}\text { Retrospective } \\
\text { cohort }\end{array}$ & 79 & Questionnaire & $59(36)$ & 'More than controls' & Memory \\
\hline Earnest, $1980^{27}$ & 3 & $\begin{array}{l}\text { Retrospective } \\
\text { cohort }\end{array}$ & 20 & $4 \mathrm{np}$ tests & 44 & $43 \%$ & Memory \\
\hline Kotila, $1984^{6}$ & 0 & $\begin{array}{l}\text { Retrospective } \\
\text { cohort }\end{array}$ & 10 & $\begin{array}{l}\text { np tests, not } \\
\text { described }\end{array}$ & $7(2.5-8)$ & $88 \%$ & Memory, visual intelligence \\
\hline Lim, $2004^{23}$ & 2 & $\begin{array}{l}\text { Retrospective } \\
\text { cohort }\end{array}$ & 11 & 12 np tests & $23(22)$ & $91 \%$ & Memory, executive functioning \\
\hline Longstreth, $1983^{37}$ & 3 & $\begin{array}{l}\text { Retrospective } \\
\text { cohort }\end{array}$ & 279 & $\begin{array}{l}\text { Classification from } \\
\text { medical records }\end{array}$ & $>24$ & $33 \%$ & Not specified \\
\hline Middelkamp, $2007^{3}$ & 5 & $\begin{array}{l}\text { Retrospective } \\
\text { cohort }\end{array}$ & 16 & Questionnaire & $24-84$ & 'High' & Not specified \\
\hline Nunes, $2003^{19}$ & 2 & $\begin{array}{l}\text { Retrospective } \\
\text { cohort }\end{array}$ & 11 & $20 \mathrm{np}$ tests & $21(10-36)$ & $45 \%$ & $\begin{array}{l}\text { Verbal, visual and spatial } \\
\text { memory, verbal fluency, } \\
\text { perceptual speed and } \\
\text { performance, language, executive } \\
\text { functioning }\end{array}$ \\
\hline Peskine, $2004^{24}$ & 0 & $\begin{array}{l}\text { Retrospective } \\
\text { cohort }\end{array}$ & 12 & $11 \mathrm{np}$ test & $?$ & $100 \%$ & $\begin{array}{l}\text { General cognitive functioning, } \\
\text { memory, executive functioning, } \\
\text { attention, apraxia, } \\
\text { communication }\end{array}$ \\
\hline Pubbwald, $2000^{7}$ & 3 & $\begin{array}{l}\text { Retrospective } \\
\text { cohort }\end{array}$ & 12 & 8 np tests & $25(7-98)$ & $100 \%$ & $\begin{array}{l}\text { Visual perception, memory, } \\
\text { attention, orientation }\end{array}$ \\
\hline Roewer, $1985^{38}$ & 1 & $\begin{array}{l}\text { Retrospective } \\
\text { cohort }\end{array}$ & 28 & Interview & $31(21)$ & $68 \%$ & Memory, concentration \\
\hline Sunnerhagen, $1996^{21}$ & 5 & $\begin{array}{l}\text { Retrospective } \\
\text { cohort }\end{array}$ & 20 & MSSE only & $23(17-44)$ & $35 \%$ & Not specified \\
\hline
\end{tabular}

MMSE = Mini-Mental State Examination; np test $=$ neuropsychological test. 


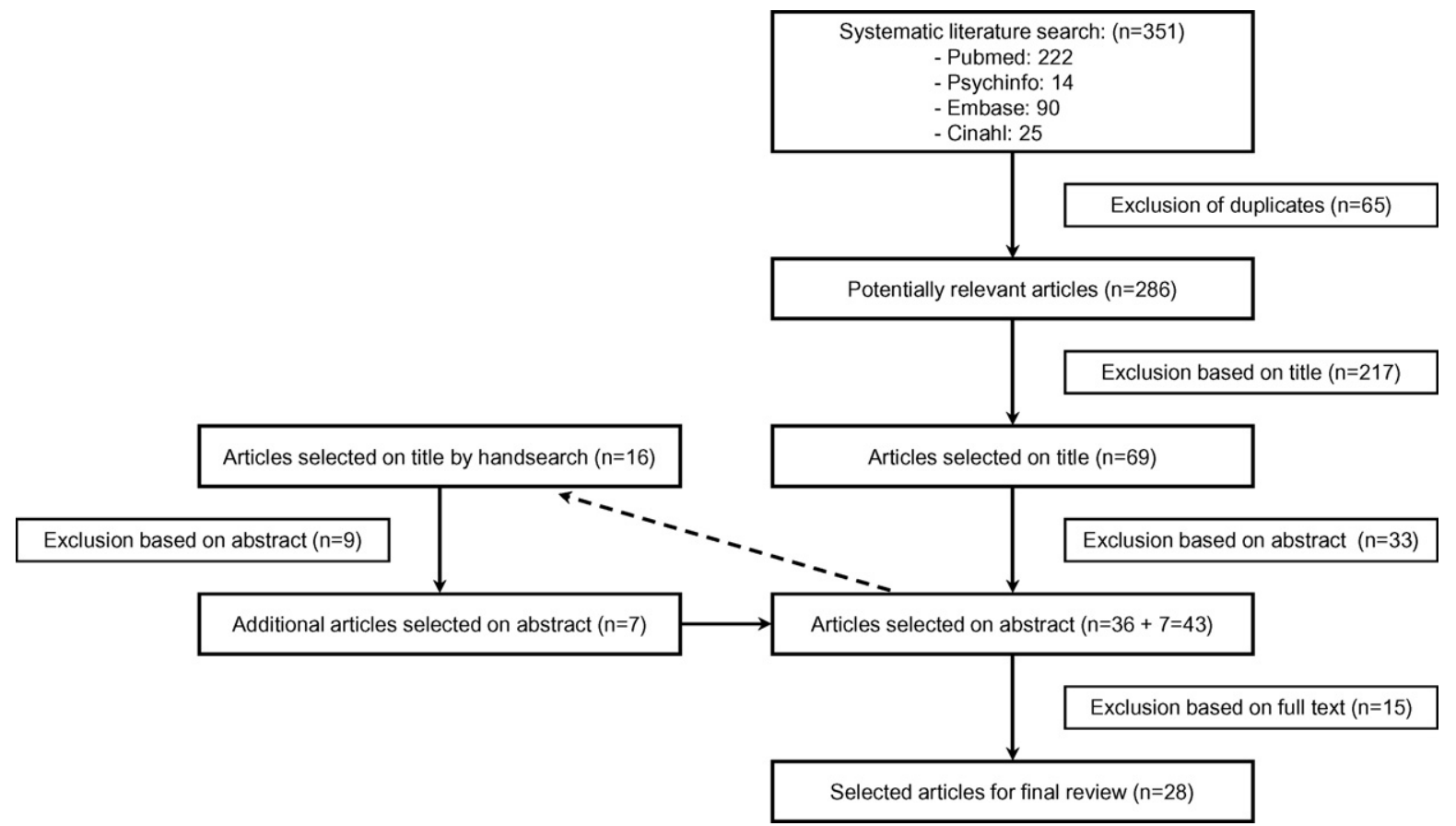

Fig. 1. Flowchart of the literature search and selection process.

\subsection{Study population}

The characteristics and results of the reviewed articles are summarised in Tables 3 and 4. In Table 3 the studies with a case-control, cross-sectional or retrospective cohort design are described briefly. In Table 4 the eight prospective studies are presented in more detail.

The study populations all included survivors of out-of-hospital cardiac arrest but several studies also contained other groups of survivors, for example, survivors of in-hospital cardiac arrest, respiratory arrest or carbon monoxide poisoning, 1,15-21 Several studies used selected populations. In six studies participants were selected based on the presence of cognitive problems or referral for rehabilitation. ${ }^{3,7,16,22-24}$ In four studies participants were excluded if they had severe cognitive impairments.,20,25,26

The number of subjects per study ranged from 10 to 308. In 11 (39\%) of the studies there were less than 20 subjects. In 10 (36\%) studies the number of subjects was between 20 and 50. Only the remaining seven (25\%) studies had more than 50 subjects.

The mean age of the participants varied between 37 years ${ }^{16}$ and 70 years. $^{22}$

\subsection{Study design, measurement instruments and follow-up}

Study designs varied considerably: five case-control studies, two cross-sectional studies, one combination of a case-control and a cross-sectional study, 12 retrospective cohort studies, seven prospective cohort studies and one study reported data from a randomised controlled trial.

The outcome measures used to assess cognitive functioning were varied: interviews, questionnaires, the Mini-Mental State Examination (MMSE) and/or other neuropsychological tests. The cognitive domains that were measured in one or more studies were orientation, attention, memory, perception, executive functioning, apraxia, verbal function and language skills, construction and concept formation/reasoning. Memory was measured most frequently, in 22 of the studies, and was further classified into episodic longterm, short-term, recall, recognition and/or visual memory. The duration of follow-up from the time of the cardiac arrest to the measurement moment showed a mean or median follow-up from 6 to 59 months, often with a wide range.

\subsection{Outcomes of the studies}

All except two studies reported that cognitive problems are common after out-of-hospital cardiac arrest. The frequency of cognitive problems ranged from $6 \%$ to $100 \%$. The three prospective studies with the highest quality scores, in which a battery of neuropsychological tests had been administered, reported cognitive problems in $42 \%, 48 \%$ and $50 \%$ of the participants, respectively. ${ }^{10,12,14}$

Most of the cognitive domains assessed were affected, and no domain escaped impairment. The most frequently impaired domains were memory, attention and executive functioning. Memory problems were reported to occur in $12-100 \%$ of the participants. Memory for novel information and delayed recall seemed to be affected most frequently. ${ }^{7,11,17}$

Five of the prospective studies reported on the changes in cognitive function over time. Two studies showed no significant changes in cognitive functioning during the follow-up period of 1 year. ${ }^{14,26}$ In contrast, two other studies showed a significant improvement in cognitive function (attention, orientation, early retention, delayed recall, reasoning and motor speed) during the first 3 months, but no further improvements up to 6 months. ${ }^{10,11}$ Scores on the MMSE showed improvements in the first months only. ${ }^{1,14}$

In some studies possible confounding factors were examined In two studies a positive relationship was found between better cognitive outcome and several resuscitation variables (fast start of resuscitation, the presence of witnesses, early start of CPR, early defibrillation, no need for and/or no delay of advanced life support, and short time to return of spontaneous circulation). ${ }^{12,13}$ In contrast, four studies did not show any relation between resuscitation variables and cognition. 5,9,14,25 Co-morbidity, 9,13 time since the cardiac arrest ${ }^{9,22}$ and sex ${ }^{5,14}$ were not related to cognitive outcome. Younger age was related to better cognitive outcome in one study, ${ }^{16}$ while the opposite was shown in the study of Bunch et al. ${ }^{25}$ In addition, several other studies showed no relationship between cognitive outcome and age at all.5,9,13,14 The influence of depression was examined in a number of studies. Although four 
Table 4

Evidence table of the selected studies with a prospective design.

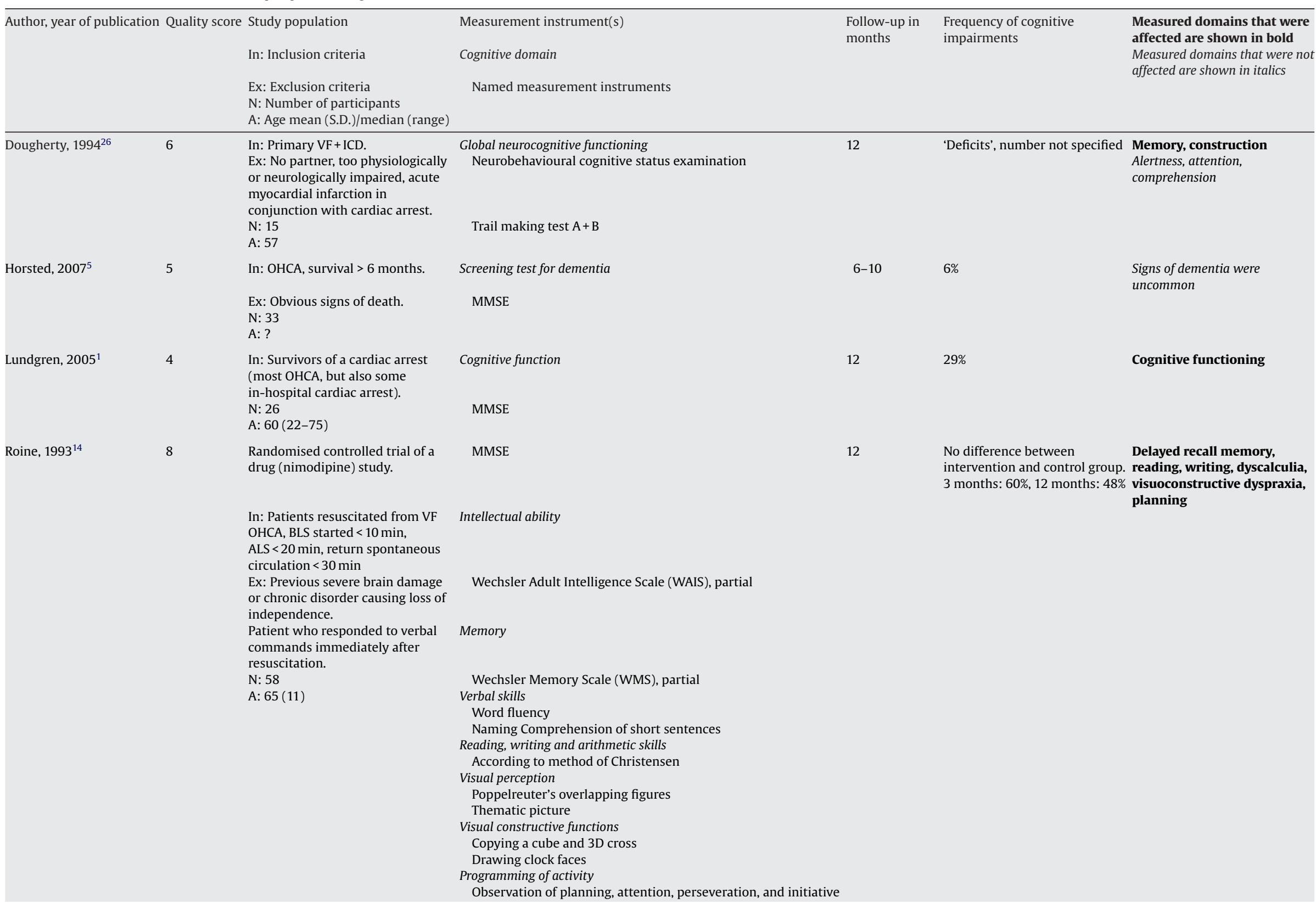




\begin{tabular}{|c|c|c|c|c|c|c|}
\hline \multirow[t]{3}{*}{ Author, year of publication } & \multirow[t]{3}{*}{ Quality score } & Study population & Measurement instrument(s) & \multirow[t]{3}{*}{$\begin{array}{l}\text { Follow-up in } \\
\text { months }\end{array}$} & \multirow[t]{3}{*}{$\begin{array}{l}\text { Frequency of cognitive } \\
\text { impairments }\end{array}$} & \multirow{3}{*}{$\begin{array}{l}\text { Measured domains that were } \\
\text { affected are shown in bold } \\
\text { Measured domains that were not } \\
\text { affected are shown in italics }\end{array}$} \\
\hline & & In: Inclusion criteria & Cognitive domain & & & \\
\hline & & $\begin{array}{l}\text { Ex: Exclusion criteria } \\
\text { N: Number of participants } \\
\text { A: Age mean (S.D.)/median (range) }\end{array}$ & Named measurement instruments & & & \\
\hline \multirow[t]{2}{*}{ Sauvé, $1996^{10}$} & \multirow[t]{2}{*}{9} & $\begin{array}{l}\text { In: Survivors of sudden cardiac } \\
\text { death. }\end{array}$ & Intellectual function & 6 & $50 \%$ & $\begin{array}{l}\text { Memory (especially delayed } \\
\text { recall and recognition) and } \\
\text { other cognitive functions } \\
\text { (numbers per domain not } \\
\text { specified) }\end{array}$ \\
\hline & & $\begin{array}{l}\mathrm{N}: 45 \\
\text { A: } 61(11)\end{array}$ & $\begin{array}{l}\text { Neurobehavioural cognitive status examination } \\
\text { Attention } \\
\text { Symbol-digit modalities test } \\
\text { Visual scanning task } \\
\text { Memory } \\
\text { Rey auditory verbal learning test } \\
\text { Memory scanning task } \\
\text { Reasoning } \\
\text { Controlled oral word association test }\end{array}$ & & & \\
\hline \multirow[t]{9}{*}{ Sauvé, 1996¹1 } & \multirow[t]{9}{*}{7} & $\begin{array}{l}\text { In: Survivors of 'aborted sudden } \\
\text { cardiac death' referred for } \\
\text { electrophysiology study, serial } \\
\text { drug testing, or implantation of ICD }\end{array}$ & Intellectual function & 6 & $29 \%$ & $\begin{array}{l}\text { Delayed recall memory, } \\
\text { motor speed, attention }\end{array}$ \\
\hline & & $\begin{array}{l}\text { Ex: History of prior brain } \\
\text { pathologic condition or psychiatric } \\
\text { illness requiring ongoing drug } \\
\text { therapy }\end{array}$ & Neurobehavioural cognitive status examination & & & Reasoning \\
\hline & & $\mathrm{N}: 25$ & Attention & & & \\
\hline & & A: $59(11)$ & $\begin{array}{l}\text { Symbol-digit modalities test } \\
\text { Visual scanning task }\end{array}$ & & & \\
\hline & & & Reasoning & & & \\
\hline & & & Controlled oral word association test & & & \\
\hline & & & $\begin{array}{l}\text { Motor speed } \\
\text { Tapping test }\end{array}$ & & & \\
\hline & & & Memory & & & \\
\hline & & & $\begin{array}{l}\text { Rey auditory verbal learning test } \\
\text { Memory scanning task }\end{array}$ & & & \\
\hline \multirow[t]{6}{*}{ Van Alem, $2004^{12}$} & \multirow[t]{6}{*}{10} & $\begin{array}{l}\text { In: Witnessed VF OHCA, discharged } \\
\text { alive }\end{array}$ & Memory & \multirow[t]{6}{*}{6} & \multirow[t]{6}{*}{$42 \%$} & Memory (12-19\%) \\
\hline & & $\begin{array}{l}\text { Ex: Witnessed by EMS, impaired } \\
\text { cognition prior to OHCA. }\end{array}$ & Rey's auditory verbal learning test (AVLT) & & & \multirow{5}{*}{$\begin{array}{l}\text { Attention, response } \\
\text { inhibition, mental flexibility } \\
\text { and motor speed (19-28\%) } \\
\text { Verbal fluency (21\%) }\end{array}$} \\
\hline & & N: 57 & Attention and response inhibition & & & \\
\hline & & A: $63(12)$ & & & & \\
\hline & & & $\begin{array}{l}\text { Divided attention, mental flexibility, and motor speed } \\
\text { Trail making test } \mathrm{A}+\mathrm{B}\end{array}$ & & & \\
\hline & & & $\begin{array}{l}\text { Verbal fluency } \\
\text { Controlled oral word association test }\end{array}$ & & & \\
\hline \multirow{3}{*}{ Van Alem, $2004^{13}$} & \multirow{3}{*}{8} & In: OHCA, discharged alive. & Cognitive functioning & \multirow{3}{*}{$7(4-20)$} & \multirow{3}{*}{$16 \%$} & \multirow{3}{*}{ Cognitive functioning } \\
\hline & & N: 174 & MMSE & & & \\
\hline & & A: $62(12)$ & & & & \\
\hline
\end{tabular}

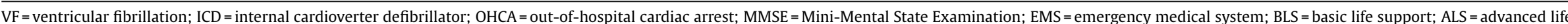
support. 
studies reported a relationship between cognitive impairments and depressive symptoms, ${ }^{17,21,11,14}$ this finding was not confirmed in the study of Grubb et al. ${ }^{9}$ Being awake at admission ${ }^{27}$ and a short time to post-arrest awakening (meaning a short duration of coma) were consistently related to better long-term cognitive functioning in three studies. ${ }^{10,11,16}$

\section{Discussion}

This systematic review revealed only a few high quality studies on the nature and frequency of long-term cognitive impairments after out-of-hospital cardiac arrest. After critically reviewing all selected articles, only three relatively large ( $n=45,57$ and 58$)$, qualitatively sound, prospective studies remained in which cognition was measured with a battery of neuropsychological tests. ${ }^{10,12,14}$ The results suggest that cognitive impairments are common after out-of-hospital cardiac arrest and that all cognitive domains can be affected, with memory being the most commonly and severely affected domain, followed by attention and executive functioning. Improvement in cognitive function over time was seen in some of the studies, but during the first 3 months only, suggesting that recovery of cognitive functioning may be limited to 3 months. However, the quality of the current evidence is not sufficient to draw final conclusions on this issue.

The quality of the reviewed articles was in general low. Therefore, caution is needed with regard to generalising the results from the reported studies to the whole population of out-of-hospital cardiac arrest survivors. Only six studies had a quality score of $7 / 10$ or above on the quality criteria list which was predominantly influenced by study design: prospective studies scored better while case-control, cross-sectional and retrospective studies tended to receive lower quality scores because they have a higher intrinsic risk of bias.

The low quality of most studies can be attributed to four important methodological weaknesses. First of all, the study populations themselves often showed a high risk of bias. Several studies described a population that did not consist of survivors of out-of-hospital cardiac arrest alone. Other studies had selected populations such as patients already referred for specialised treatment or already having evident cognitive problems; these will probably be more seriously affected patients. On the other hand, there were also studies that excluded severely impaired patients.

Second, the sample size was small in most of the studies. Only seven studies included 50 subjects or more. The small sample sizes coupled with the biases already discussed make it difficult to generalise the results to the whole population of survivors of out-of-hospital cardiac arrest.

Third, cognitive functioning was measured differently in each study, probably because there is no standard protocol for testing cognitive function in hypoxic brain injured patients. Due to the heterogeneity of the studies statistical pooling was not possible. In four studies the assessment of cognitive function was solely based on the Mini-Mental State Examination (MMSE) which has been shown to be insensitive at detecting cognitive impairments. ${ }^{28}$ These studies reported a lower frequency of cognitive impairments than other studies using a battery of neuropsychological tests. Nevertheless, a substantial number of studies did conduct a good battery of neuropsychological tests but still the cut-off scores, used to define cognitive impairment, differed between the studies.

Lastly, possible confounding factors were not consistently taken into account. Most of the studies that did consider confounding factors showed contradictory results. It is currently unclear how age, depression, the duration of the cardiac arrest and other variables related to the resuscitation affect cognitive functioning. However, there was agreement between several studies that co-morbidity, time since the cardiac arrest and sex are not related to the sever- ity of cognitive impairment. In addition, being awake at admission and a short duration of coma were consistently related to better long-term cognitive functioning.

This systematic review also might have been subject to bias. Although we performed an extensive literature search without language restriction, it is possible that we have missed some articles. Furthermore, bias may arise both in abstracting data and in scoring quality. We tried to limit the risk of subjectivity by using a standardised criteria list and by using two people to abstract and check data independently. Lastly, using a quality score makes it easier to compare studies but takes away the detailed information sometimes needed to judge the quality of a study.

One main finding of this systematic review is that cognitive problems seem common in survivors of out-of-hospital cardiac arrest. In the three best prospective studies, cognitive problems were reported in $42 \%, 48 \%$ and $50 \%$ of the participants, respectively. ${ }^{10,12,14}$ This indicates that about half of the survivors of out-of-hospital cardiac arrest suffer from cognitive impairments. The cognitive domains that were affected most frequently were memory, attention and executive functioning but these were also the domains that were measured most often. Memory problems were reported most frequently. A possible explanation for this is that the hippocampus, a brain structure important for the storage of information, is very sensitive to decreased cerebral perfusion. ${ }^{29,30}$ Furthermore, memory seems to be affected by the global cerebral atrophy seen after out-of-hospital cardiac arrest. ${ }^{31}$ Global cerebral atrophy may also explain why so many cognitive domains can be impaired after cardiac arrest. The biological mechanisms involved in the development of global ischaemic brain injury are complex and the subject of ongoing research.

Hypothermia in comatose cardiac arrest survivors improves so-called neurological outcome. ${ }^{32}$ However, a study by Tiainen et al. could not demonstrate significant positive effects of hypothermia on cognitive functioning. ${ }^{33}$ This discrepancy may arise because neurological outcome is often measured using the Glasgow-Pittsburgh Cerebral Performance Categories (CPC), as is recommended in the 'Utstein' criteria. ${ }^{34}$ Although a CPC score of 1 or 2 is commonly regarded as 'good outcome', it includes subjects with 'mild to moderate' cognitive impairments, such as dysphasia and permanent memory or mental changes. Furthermore, the $\mathrm{CPC}$ seems insensitive to more subtle cognitive impairments. Therefore, we advocate the use of neuropsychological testing (including at least tests for memory, attention and executive functioning) in determining outcome after cardiac arrest. A neuropsychologist can be consulted to select and administer an appropriate set of neuropscyhological tests. Suggestions of neuropsychological tests can be found in a design article by Moulaert et al. ${ }^{35}$

For clinicians it is important to be aware that cognitive impairments occur frequently after out-of-hospital cardiac arrest. Unfortunately, cognitive impairments can be easily overlooked so that, unless one explicitly screens for them, they can easily be missed. This is of concern because cognitive problems may have a high impact on a person's daily functioning and quality of life. A large prospective trial is now needed to collect reliable data on the prevalence, severity and course of cognitive problems after a cardiac arrest, and to relate the cognitive losses identified to possible limitations in daily life, participation in society and quality of life.

\section{Ethical approval}

Ethical approval was not required.

\section{Contributions}

V. Moulaert was the first reviewer, performed the literature search and is the guarantor of this study. J. Verbunt acted as second 
reviewer. Both reviewers read all the selected titles and abstracts and selected the final articles for the review. C. van Heugten was the third reviewer and acted as a mediator in case of disagreement between the two reviewers and then made the final decision. All authors participated in the selection of a quality criteria scoring list and contributed to the protocol and final manuscript.

\section{Funding}

The study was funded by the Netherlands Organisation for Health Research and Development (ZON/MW) and Fonds Nuts/Ohra.

\section{Conflict of interest}

The authors declare that they have no competing interests.

\section{Acknowledgements}

We would like to thank Jill Hayden for providing us with the original version of her quality criteria list. We kindly acknowledge Daniel Keszthelyi and Ward Vanagt for their help in translating the Hungarian and French articles, respectively.

Appendix A. Keywords and limits used in the literature search

\begin{tabular}{|c|c|c|c|}
\hline \multirow[t]{2}{*}{ Database } & \multicolumn{2}{|l|}{ Keywords } & \multirow[t]{2}{*}{ Limits } \\
\hline & Population & Cognitive outcome & \\
\hline Pubmed & $\begin{array}{l}\text { HEART ARREST } \\
\text { Heart arrest }^{*} \\
\text { Asystole }^{*} \\
\text { Cardiac arrest }^{*} \\
\text { Cardiopulmonary arrest }^{*} \\
\text { Circulatory arrest }^{*} \\
\text { Cardiac sudden death }^{*} \\
\text { Sudden cardiac death } \\
\text { RESUSCITATION } \\
\text { Resuscitation } \\
\text { Cardiopulmonary resuscitation } \\
\text { cpr }\end{array}$ & $\begin{array}{l}\text { COGNITION DISORDERS } \\
\text { Cognition disorder } \\
\text { Cognitive } \\
\text { MEMORY DISORDERS } \\
\text { Memory disorder }{ }^{*} \\
\text { Amnesia } \\
\text { NEUROPSYCHOLOGICAL TESTS } \\
\text { Neuropsychological test }\end{array}$ & $\begin{array}{l}\text { All adults: 19+ } \\
\text { 1980-2006 }\end{array}$ \\
\hline PsychInfo & $\begin{array}{l}\text { Heart arrest } \\
\text { Asystole } \\
\text { Cardiac arrest }^{*} \\
\text { Cardiopulmonary arrest } \\
\text { Circulatory arrest } \\
\text { Cardiac sudden death } \\
\text { Sudden cardiac death } \\
\text { Resuscitation } \\
\text { Cardiopulmonary resuscitation } \\
\text { cpr }\end{array}$ & $\begin{array}{l}\text { COGNITIVE IMPAIRMENT } \\
\text { MEMORY-DISORDERS } \\
\text { NEUROPSYCHOLOGICAL ASSESSMENT }\end{array}$ & $\begin{array}{l}\text { Adult }(18+) \\
1980-2006\end{array}$ \\
\hline Cinahl & $\begin{array}{l}\text { HEART ARREST } \\
\text { Asystole }^{*} \\
\text { Cardiac arrest }^{*} \\
\text { Cardiopulmonary arrest }^{*} \\
\text { Circulatory arrest } \\
\text { DEATH-SUDDEN-CARDIAC } \\
\text { RESUSCITATION } \\
\text { Cardiopulmonary resuscitation } \\
\text { cpr }\end{array}$ & $\begin{array}{l}\text { COGNITION DISORDERS } \\
\text { MEMORY DISORDERS } \\
\text { NEUROPSYCHOLOGICAL TESTS }\end{array}$ & $\begin{array}{l}\text { And adult } \\
\text { 1980-2006 }\end{array}$ \\
\hline Embase & $\begin{array}{l}\text { HEART ARREST } \\
\text { ASYSTOLE } \\
\text { Cardiac arrest } \\
\text { Cardiopulmonary arrest }^{*} \\
\text { Circulatory arrest }^{*} \\
\text { SUDDEN DEATH } \\
\text { RESUSCITATION } \\
\text { Cardiopulmonary resuscitation } \\
\text { cpr }\end{array}$ & $\begin{array}{l}\text { COGNITIVE DEFECT } \\
\text { MEMORY DISORDER } \\
\text { NEUROPSYCHOLOGICAL TEST }\end{array}$ & $\begin{array}{l}\text { And adult } \\
\text { 1986-2006 }\end{array}$ \\
\hline
\end{tabular}

MesH or thesaurus terms are indicated in capital letters. Text words are indicated in regular letters.

* Truncation. 


\section{References}

1. Lundgren-Nilsson A, Rosen H, Hofgren C, Sunnerhagen KS. The first year after successful cardiac resuscitation: function, activity, participation and quality of life. Resuscitation 2005;66:285-9.

2. de Vos R, de Haes HC, Koster RW, de Haan RJ. Quality of survival after cardiopulmonary resuscitation. Arch Intern Med 1999;159:249-54.

3. Middelkamp W, Moulaert VR, Verbunt JA, van Heugten CM, Bakx WG, Wade DT. Life after survival: long-term daily life functioning and quality of life of patients with hypoxic brain injury as a result of a cardiac arrest. Clin Rehabil 2007;21:425-31.

4. Bertini G, Giglioli C, Giovannini F, et al. Neuropsychological outcome of survivors of out-of-hospital cardiac arrest. J Emerg Med 1990;8:407-12.

5. Horsted TI, Rasmussen LS, Meyhoff CS, Nielsen SL. Long-term prognosis after out-of-hospital cardiac arrest. Resuscitation 2007;72:214-8.

6. Kotila M, Kajaste S. Neurological and neuropsychological symptoms after cardiac arrest. Acta Neurol Scand 1984;69:337-8.

7. Pusswald G, Fertl E, Faltl M, Auff E. Neurological rehabilitation of severely disabled cardiac arrest survivors. Part II. Life situation of patients and families after treatment. Resuscitation 2000;47:241-8.

8. Hayden JA, Cote P, Bombardier C. Evaluation of the quality of prognosis studies in systematic reviews. Ann Intern Med 2006;144:427-37.

9. Grubb NR, O'Carroll R, Cobbe SM, Sirel J, Fox KA. Chronic memory impairment after cardiac arrest outside hospital. BMJ 1996;313:143-6.

10. Sauve MJ, Doolittle N, Walker JA, Paul SM, Scheinman MM. Factors associated with cognitive recovery after cardiopulmonary resuscitation. Am J Crit Care 1996;5:127-39.

11. Sauve MJ, Walker JA, Massa SM, Winkle RA, Scheinman MM. Patterns of cognitive recovery in sudden cardiac arrest survivors: the pilot study. Heart Lung 1996;25:172-81.

12. van Alem AP, de Vos R, Schmand B, Koster RW. Cognitive impairment in survivors of out-of-hospital cardiac arrest. Am Heart J 2004;148:416-21.

13. van Alem AP, Waalewijn RA, Koster RW, de Vos R. Assessment of quality of life and cognitive function after out-of-hospital cardiac arrest with successful resuscitation. Am J Cardiol 2004;93:131-5.

14. Roine RO, Kajaste S, Kaste M. Neuropsychological sequelae of cardiac arrest.JAMA 1993;269:237-42.

15. Barat M, Blanchard JY, Darriet D, Giroire JM, Daverat P, Mazaux JM. Long-term cognitive impairments following prolonged cerebral anoxia. Influence on subsequent functional ability. Ann Readapt Med Phys 1989;32:657-68.

16. Groswasser Z, Cohen M, Costeff $\mathrm{H}$. Rehabilitation outcome after anoxic brain damage. Arch Phys Med Rehabil 1989;70:186-8.

17. Hopkins RO, Kesner RP, Goldstein M. Memory for novel and familiar spatial and linguistic temporal distance information in hypoxic subjects. J Int Neuropsychol Soc 1995; 1:454-68.

18. Nielsen JR, Gram L, Rasmussen LP, et al. Intellectual and social function of patients surviving cardiac arrest outside the hospital. Acta Med Scand 1983;213:37-9.

19. Nunes B, Pais J, Garcia R, Magalhaes Z, Granja C, Silva MC. Cardiac arrest: longterm cognitive and imaging analysis. Resuscitation 2003;57:287-97.

20. Sauve MJ. Long-term physical functioning and psychosocial adjustment in survivors of sudden cardiac death. Heart Lung 1995;24:133-44.
21. Sunnerhagen KS, Johansson O, Herlitz J, Grimby G. Life after cardiac arrest; a retrospective study. Resuscitation 1996;31:135-40.

22. Drysdale EE, Grubb NR, Fox KA, O'Carroll RE. Chronicity of memory impairment in long-term out-of-hospital cardiac arrest survivors. Resuscitation 2000;47:27-32.

23. Lim C, Alexander MP, LaFleche G, Schnyer DM, Verfaellie M. The neurological and cognitive sequelae of cardiac arrest. Neurology 2004;63:1774-8.

24. Peskine A, Picq C, Pradat-Diehl P. Cerebral anoxia and disability. Brain Injury 2004; 18:1243-54.

25. Bunch TJ, White RD, Smith GE, et al. Long-term subjective memory function in ventricular fibrillation out-of-hospital cardiac arrest survivors resuscitated by early defibrillation. Resuscitation 2004;60:189-95

26. Dougherty CM. Longitudinal recovery following sudden cardiac arrest and internal cardioverter defibrillator implantation: survivors and their families. Am J Crit Care 1994;3:145-54.

27. Earnest MP, Yarnell PR, Merrill SL, Knapp GL. Long-term survival and neurologic status after resuscitation from out-of-hospital cardiac arrest. Neurology 1980;30:1298-302.

28. Nys GM, van Zandvoort MJ, de Kort PL, Jansen BP, Kappelle LJ, de Haan EH. Restrictions of the Mini-Mental State Examination in acute stroke. Arch Clin Neuropsychol 2005;20:623-9.

29. Back T, Hemmen T, Schuler OG. Lesion evolution in cerebral ischemia. J Neurol 2004;251:388-97.

30. Harukuni I, Bhardwaj A. Mechanisms of brain injury after global cerebral ischemia. Neurol Clin 2006;24:1-21.

31. Grubb NR, Fox KA, Smith K, et al. Memory impairment in out-of-hospital cardiac arrest survivors is associated with global reduction in brain volume, not focal hippocampal injury. Stroke 2000;31:1509-14.

32. Cheung KW, Green RS, Magee KD. Systematic review of randomized controlled trials of therapeutic hypothermia as a neuroprotectant in post cardiac arrest patients. CJEM 2006;8:329-37.

33. Tiainen M, Poutiainen E, Kovala T, Takkunen O, Happola O, Roine RO. Cognitive and neurophysiological outcome of cardiac arrest survivors treated with therapeutic hypothermia. Stroke 2007;38:2303-8.

34. Recommended guidelines for uniform reporting of data from out-of-hospital cardiac arrest: the 'Utstein style'. Prepared by a Task Force of Representatives from the European Resuscitation Council, American Heart Association, Heart and Stroke Foundation of Canada, Australian Resuscitation Council. Resuscitation $1991 ; 22: 1-26$

35. Moulaert VR, Verbunt JA, van Heugten CM, et al. Activity and Life After Survival of a Cardiac Arrest (ALASCA) and the effectiveness of an early intervention service: design of a randomised controlled trial. BMC Cardiovasc Disord 2007; 7:26.

36. Bergner L, Hallstrom AP, Bergner M, Eisenberg MS, Cobb LA. Health status of survivors of cardiac arrest and of myocardial infarction controls. Am J Public Health 1985;75:1321-3.

37. Longstreth Jr WT, Inui TS, Cobb LA, Copass MK. Neurologic recovery after outof-hospital cardiac arrest. Ann Intern Med 1983;98:588-92.

38. Roewer N, Kloss T, Puschel K. Long-term result and quality of life following preclinical cardiopulmonary resuscitation. Anasth Intensivther Notfallmed 1985;20:244-50. 